\title{
PENGEMBANGAN PERANGKAT PEMBELAJARAN BERBANTUAN MEDIA ANIMASI INTERAKTIF BERBASIS GAME EDUKASI UNTUK MENINGKATKAN MOTIVASI DAN HASIL BELAJAR SISWA
}

\author{
Laely Adyani' ${ }^{1}$, Rudiana Agustini' ${ }^{2)}$, Raharjo ${ }^{3)}$ \\ ${ }^{1)}$ Mahasiswa Program Studi Pendidikan Sains, Program Pascasarjana Universitas Negeri Surabaya \\ ${ }^{2),}{ }^{30}$ Dosen Pascasarjana Prodi Pendidikan Sains Univesrtitas Negeri Surabaya
}

\begin{abstract}
The aim of this research is to produce learning material and educational game that feasible to improve student's motivation and learning achievement. The development of learning material and educational game used Four D Model and was tested in class XI of SMA Muhammadiyah 2 Sidoarjo second semester in academic year 2013/2014 with One-group PretestPosttest Design. The data collection used validation method, observation, test, and quetionnaires. The data analysis techniques used descriptive analysis of quantitative, qualitative, and correlative hypothesis test. The results of this research are: 1) Learning material and educational game developed has a valid category; 2) Learning material and educational game in terms of feasibility of lesson plans with good category.3) Student's activities in accordance with the direct instruction model with the highest activities are learning by educational game, doing student activity sheet, and listening to the teacher explanation. 4) 91.67 percent of students are getting completeness and the n-gain score with high category. 5) Student's motivation with high category. 6) The correlation of student's learning achievement and motivation level is significant and showed a moderate positive correlation. It's conclusion that the learning material and educational game are feasible to improve student's motivation and learning achievement.
\end{abstract}

Keywords: Learning material, educational game, motivation, learning achievement.

\begin{abstract}
Abstrak: Penelitian ini bertujuan menghasilkan perangkat pembelajaran dan media game edukasi yang layak untuk meningkatkan motivasi dan hasil belajar siswa. Pengembangan perangkat dan media game edukasi menggunakan model Four-D dan diujicobakan di kelas XI SMA Muhammadiyah 2 Sidoarjo semester genap tahun ajaran 2013/2014 dengan One-Group Pretest-Posttest Design. Pengumpulan data menggunakan metode validasi, observasi, tes, dan angket. Teknik analisis data menggunakan analisis deskriptif kuantitatif, kualitatif dan uji hipotesis korelatif. Hasil penelitian ini menunjukkan: 1) Perangkat pembelajaran dan media game edukasi yang dikembangkan berkategori valid; 2) Perangkat pembelajaran dan media game edukasi ditinjau dari keterlaksanaan RPP berkategori baik; 3) Aktivitas siswa sesuai dengan model pembelajaran langsung dengan aktivitas tertinggi yaitu: mengoperasikan game edukasi, mengerjakan LKS, dan memperhatikan penjelasan guru; 4) 91.67\% siswa tuntas dalam pembelajaran dengan N-gain berkategori tinggi; 5) Motivasi siswa dalam pembelajaran berkategori baik; 6) Korelasi antara motivasi dan hasil belajar siswa adalah signifikan dengan kekuatan korelasi yang cukup kuat. Disimpulkan bahwa perangkat pembelajaran dan media game edukasi yang dikembangkan adalah layak dan dapat digunakan untuk meningkatkan motivasi dan hasil belajar siswa.
\end{abstract}

Kata kunci: Perangkat pembelajaran, game dukasi, motivasi, hasil belajar

\section{PENDAHULUAN}

Kegiatan belajar mengajar merupakan suatu proses yang melibatkan banyak komponen yang saling berinteraksi didalamnya. Salah satu komponen dalam proses tersebut adalah guru. Komponen pendukung lainnya yang turut serta mempengaruhi keberhasilan belajar mengajar adalah model mengajar dan media pembelajaran yang digunakan. Menurut Hamalik (2010), tujuan proses belajar mengajar dapat dicapai dengan baik bila ditunjang oleh berbagai faktor, antara lain media pendidikan.
Materi sistem saraf merupakan salah satu materi Biologi yang bersifat abstrak sehingga sulit dalam pelaksanaan pembelajarannya. Mulyani (2009) menjelaskan bahwa sistem saraf mempunyai karakteristik materi yang abstrak dan rumit, salah satunya karena berhubungan dengan mekanisme fisika dan kimiawi yang komplek. Materi sistem saraf mempunyai empat prinsip penting, yaitu mekanisme sebab akibat, hubungan antara struktur dan fungsi, aliran informasi, dan homeostatis

Karakteristik materi yang cukup sulit tersebut 
merupakan salah satu faktor yang mempengaruhi rendahnya kemampuan siswa dalam memahami konsep-konsep dalam sistem saraf dan mengakibatkan rendahnya hasil belajar siswa.

Pemahaman siswa yang kurang terhadap konsepkonsep tersebut kemungkinan tidak hanya dipengaruhi oleh kemampuan siswa yang rendah dalam menerima pelajaran yang disampaikan oleh guru, tetapi juga dipengaruhi oleh kemampuan guru dalam mengelola kegiatan belajar mengajar, metode serta media pembelajaran yang digunakan. Pemilihan media pembelajaran yang tepat dan menarik dapat membantu siswa dalam memahami materi yang memiliki karakteristik yang relatif abstrak dan rumit.

Salah satu media yang menarik dan dapat dimanfaatkan oleh guru dalam proses pembelajaran adalah media animasi pembelajaran. Menurut Suheri (2008), animasi merupakan suatu tehnik menampilkan gambar berurut sedemikian rupa sehingga nampak adanya ilustrasi gerakan pada gambar yang ditampilkan. Furoidah (2009) menjelaskan bahwa media animasi pembelajaran memiliki kemampuan untuk memaparkan sesuatu yang rumit atau komplek serta sulit dijelaskan dengan hanya menggunakan gambar atau kata-kata saja. Media animasi pembelajaran juga dapat digunakan untuk menjelaskan materi yang secara nyata tidak dapat terlihat oleh mata.

Berdasarkan keleluasaan pengguna dalam mengontrol media animasi yang digunakan maka media animasi dibagi menjadi dua jenis, yakni media animasi non interaktif dan media animasi interaktif. Media animasi non interaktif merupakan jenis media animasi dimana pengguna bertindak pasif dan menyaksikan adegan demi adegan hanya secara berurutan saja, sedangkan pada media animasi interaktif pengguna dapat memilih secara aktif adegan yang diinginkan. Pengguna bahkan dapat bermain dengan simulasi dan permainan yang disediakan.

Game edukasi merupakan salah satu pilihan media pembelajaran yang menarik dikarenakan pula adanya kecenderungan usia remaja yang sangat menyukai game sehingga dapat dimanfaatkan dengan mengintegrasikan game dalam suatu media animasi interaktif untuk menghasilkan suatu media pembelajaran yang menarik dan dapat meningkatkan motivasi belajar siswa.

Penggunaan game edukasi dalam media animasi interaktif diharapkan dapat meningkatkan motivasi belajar siswa, karena dalam game edukasi siswa dilibatkan secara aktif dalam proses pembelajaran yang dikemas dalam permainan, sehingga rasa ingin tahu siswa terhadap materi yang akan dipelajarinya akan meningkat, dengan demikian dapat memberikan pengaruh positif terhadap motivasi belajar siswa.
Berdasarkan latar belakang masalah yang telah diuraikan maka rumusan masalah umum dalam penelitian ini adalah: bagaimanakah kelayakan perangkat pembelajaran dan media animasi interaktif berbasis game edukasi yang dikembangkan dalam meningkatkan motivasi dan hasil belajar siswa?

Masalah-masalah penelitian yang dapat dirumuskan untuk menjawab rumusan masalah umum tersebut adalah sebagai berikut:

1. Bagaimanakah validitas perangkat pembelajaran berbantuan media animasi interaktif berbasis game edukasi yang di kembangkan?

2. Bagaimanakah keterlaksanaan pembelajaran menggunakan perangkat pembelajaran berbantuan media animasi interaktif berbasis game edukasi yang di kembangkan?

3. Bagaimanakan aktivitas siswa dalam kegiatan pembelajaran menggunakan perangkat pembelajaran berbantuan media animasi interaktif berbasis game edukasi yang di kembangkan?

4. Bagaimanakah motivasi siswa dalam mengikuti pembelajaran menggunakan perangkat pembelajaran berbantuan media animasi interaktif berbasis game edukasi yang di kembangkan?

5. Bagaimanakah ketuntasan hasil belajar siswa setelah mengikuti kegiatan pembelajaran menggunakan perangkat pembelajaran berbantuan media animasi interaktif berbasis game edukasi yang dikembangkan?

6. Bagaimanakah korelasi antara motivasi dan hasil belajar siswa?

\section{METODE PENELITIAN}

Penelitian ini merupakan jenis penelitian pengembangan, yakni pengembangan perangkat dan media pembelajaran yang mengikuti Four D Models. Perangkat yang dikembangkan dilengkapi media animasi interaktif berbasis game edukasi pada materi sistem saraf, dan selanjutnya akan di ujicobakan dalam pembelajaran di kelas dengan model pengajaran langsung di SMA Muhammadiyah 2 Sidoarjo kelas XI semester genap tahun pelajaran 2013-2014. Perangkat pembelajaran yang dikembangkan peneliti meliputi: rencana pelaksanaan pembelajaran (RPP) yang dilengkapi animasi interaktif berbasis game edukasi, lembar kegiatan siswa (LKS), dan tes hasil belajar (THB).

Proses pengembangan instrumen ini meliputi empat tahap yaitu define (pendefinisian), design (perancangan), develop (pengembangan), dan disseminate (penyebaran), akan tetapi pada penelitian ini hanya sampai tahap pengembangan saja.

Skema pengembangan model pembelajaran Four$D$ seperti Gambar 1 berikut: 


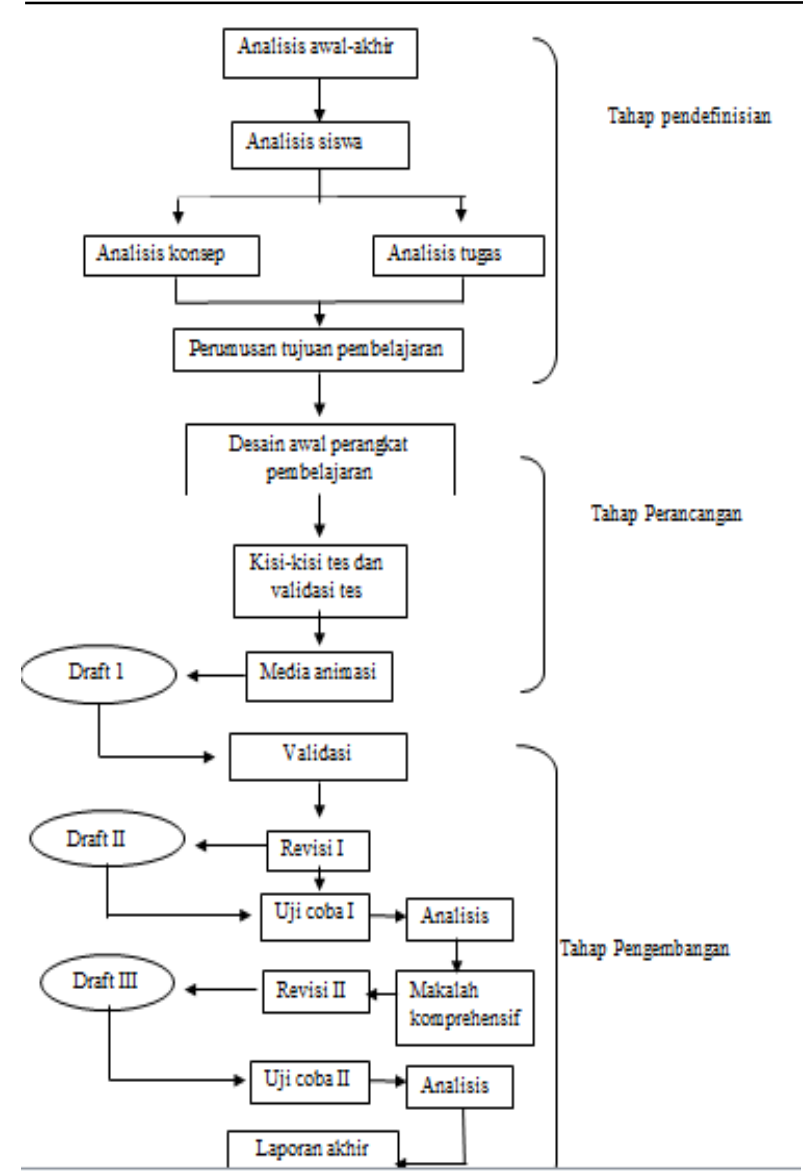

Gambar 1. Rancangan Pembelajaran Four-D Model (diadaptasi dari Thiagarajan, 1974).

\section{A. Rancangan Uji Coba}

Rancangan uji coba perangkat yang digunakan pada penelitian ini adalah One Group Pretest-Posttest Design karena hanya menggunakan satu kelompok saja tanpa adanya kelompok pembanding, seperti digambarkan berikut:

\section{$\begin{array}{lll}\mathbf{O}_{1} & \mathbf{X} & \mathbf{O}_{2}\end{array}$}

Keterangan:

$\mathrm{O}_{1}$ : Uji awal (pretest), untuk mengetahui penguasaan siswa terhadap materi sistem saraf sebelum pembelajaran berlangsung.

$\mathrm{X}$ : Perlakuan pembelajaran menggunakan media game edukasi dan perangkat pembelajaran yang dikembangkan.

$\mathrm{O}_{2}$ : Uji akhir (post test), untuk mengetahui penguasaan siswa terhadap materi sistem saraf sesudah pembelajaran berlangsung.

\section{B. Tehnik Analisis Data.}

Analisis data dalam penelitian ini menggunakan statistik deskriptif. Dalam penelitian ini dilakukan analisis terhadap: data validitas perangkat dan media, hasil pengamatan aktivitas siswa dalam pembelajaran, hasil pengamatan keterlaksanaan kegiatan pembelajaran, hasil angket motivasi siswa, dan analisis tes hasil belajar.
1. Analisis Data Validitas Perangkat dan Media Pembelajaran

Analisis terhadap validasi perangkat dan media pembelajaran dilakukan secara deskriptif kualitatif yang dilakukan dengan menghitung rata-rata skor yang diberikan oleh semua validator pada setiap media dan perangkat yang dikembangkan. Skor rata-rata ini dibandingkan dengan selang tingkat validitas. Skor rata-rata untuk RPP, LKS, dan media game edukasi dibandingkan dengan selang tingkat validitas pada Tabel 1sedangkan untuk skor rata-rata Tes Hasil Belajar dibandingkan dengan selang tingkat validitas pada Tabel 2 berikut:

Tabel 1. Selang Tingkat Validitas untuk RPP, LKS, dan Media Game Edukasi

\begin{tabular}{|c|l|l|}
\hline Selang & \multicolumn{1}{|c|}{$\begin{array}{c}\text { Tingkat } \\
\text { validitas }\end{array}$} & \multicolumn{1}{|c|}{ Keterangan } \\
\hline $1,0-1,5$ & Tidak baik & $\begin{array}{l}\text { Belum dapat } \\
\text { digunakan, } \\
\text { memerlukan konsultasi }\end{array}$ \\
\hline $1,6-2,5$ & $\begin{array}{l}\text { Kurang } \\
\text { baik }\end{array}$ & $\begin{array}{l}\text { Dapat digunakan } \\
\text { dengan banyak revisi }\end{array}$ \\
\hline $2,6-3,5$ & Baik & $\begin{array}{l}\text { Dapat digunakan } \\
\text { dengan sedikit revisi }\end{array}$ \\
\hline $3,6-4,0$ & Sangat baik & $\begin{array}{l}\text { Dapat digunakan tanpa } \\
\text { revisi }\end{array}$ \\
\hline
\end{tabular}

(Ratumanan dan Laurens, 2006)

Tabel 2. Selang Tingkat Validitas untuk Tes Hasil Belajar

\begin{tabular}{|c|l|l|l|}
\hline Selang & $\begin{array}{l}\text { Tingkat } \\
\text { validitas } \\
\text { Isi }\end{array}$ & $\begin{array}{l}\text { Validitas } \\
\text { Bahasa dan } \\
\text { Penulisan } \\
\text { Soal }\end{array}$ & Kesimpulan \\
\hline $1,0-1,5$ & $\begin{array}{l}\text { Tidak } \\
\text { valid (Tv) }\end{array}$ & $\begin{array}{l}\text { Tidak dapat } \\
\text { dipahami } \\
\text { (Tdp) }\end{array}$ & $\begin{array}{l}\text { Belum dapat } \\
\text { digunakan, } \\
\text { memerlukan } \\
\text { konsultasi (Pk) }\end{array}$ \\
\hline $1,6-2,5$ & $\begin{array}{l}\text { Kurang } \\
\text { valid } \\
\text { (Kv) }\end{array}$ & $\begin{array}{l}\text { Kurang dapat } \\
\text { dipahami } \\
\text { (Kdp) }\end{array}$ & $\begin{array}{l}\text { Dapat } \\
\text { digunakan } \\
\text { dengan revisi } \\
\text { besar (Rb) }\end{array}$ \\
\hline $2,6-3,5$ & $\begin{array}{l}\text { Cukup } \\
\text { valid } \\
\text { (Cv) }\end{array}$ & $\begin{array}{l}\text { Dapat } \\
\text { dipahami } \\
\text { (Dp) }\end{array}$ & $\begin{array}{l}\text { Dapat } \\
\text { digunakan } \\
\text { dengan revisi } \\
\text { kecil (Rk) }\end{array}$ \\
\hline $3,6-4,0$ & Valid (V) & $\begin{array}{l}\text { Sangat dapat } \\
\text { dipahami } \\
\text { (Sdp) }\end{array}$ & $\begin{array}{l}\text { Dapat } \\
\text { digunakan } \\
\text { tanpa revisi } \\
\text { (Tr) }\end{array}$ \\
\hline
\end{tabular}

(Diadaptasi dari Ratumanan dan Laurens, 2006)

2. Analisis Tes Hasil belajar

a. Ketercapaian Indikator

Satu indikator tercapai apabila persentase (P) siswa yang mencapai indikator tersebut $\geq 75 \%$.

$\left[P=\frac{\text { Jumlah siswa yang mencapai indikator tersebut }}{\text { Jumlah seluruh siswa }}\right]$ 


\section{b. Ketuntasan Individual}

Seorang siswa dikatakan tuntas secara individual apabila persentase $(\mathrm{P})$ ketuntasan yang dicapai sebesar $\geq 75 \%$.

$$
\left[P \text { individual }=\frac{\text { Jumlah skor yang diperoleh }}{\text { Skor maksimal }} \times 100 \%\right]
$$

\section{c. Analisis N-gain score}

Analisis $\mathrm{N}$-gain score merupakan analisis yang dilakukan secara deskriptif kualitatif untuk mengetahui pengaruh pembelajaran terhadap hasil belajar (Hake, 1999) dengan rumus sebagai berikut:

$$
\langle g\rangle=\frac{S \text { post }-S \text { pre }}{S \text { mak }-S \text { pre }}
$$

Keterangan:

$$
\begin{aligned}
& \langle g\rangle \quad=\text { nilai gain (peningkatan hasil belajar } \\
& \text { siswa) } \\
& \mathrm{S}_{\text {post }}=\text { nilai post test } \\
& \mathrm{S}_{\text {pre }}=\text { nilai pre test } \\
& \mathrm{S}_{\mathrm{mak}}=\text { nilai maksimal }
\end{aligned}
$$

Gain menunjukkan perbedaan penguasaan atau pemahaman konsep siswa sebelum dan setelah diberi perlakuan. Kriteria N-gain menurut Hake (1999) terbagi atas tiga tingkatan yaitu:

1) jika $\langle g\rangle \geq 0,7$ termasuk kategori pembelajaran dengan gain tinggi

2) jika $0,7 \geq\langle g\rangle \geq 0,3$, termasuk kategori pembelajaran dengan gain sedang

3) jika $\langle g\rangle \leq 0,3$ termasuk kategori pembelajaran dengan gain rendah.

\section{d. Indeks Sensitivitas butir soal}

Selanjutnya untuk mengetahui indeks sensitivitas butir soal terhadap efek-efek pembelajaran digunakan rumus-rumus sebagai berikut (Gronlund, 1985):

$$
S=\frac{R a-R b}{T}=P a-P b
$$

Keterangan :

$\mathrm{S}=$ Sensitivitas butir soal

$\mathrm{Ra}=$ Jumlah siswa yang menjawab benar pada tes akhir

$\mathrm{Rb}=$ Jumlah siswa yang menjawab benar pada tes awal

$\mathrm{T}=$ Jumlah siswa yang mengikuti tes

$\mathrm{Pa}=$ Proporsi jawaban benar uji akhir

$\mathrm{Pb}=$ Proporsi jawaban benar uji awal

Indeks butir soal yang efektif terdapat antara 0,00 dan 1,00. Nilai positif yang lebih besar menyatakan butir soal yang lebih besar kepekaannya terhadap efek- efek pembelajaran. Butir soal yang peka terhadap efekefek pembelajaran mempunyai sensitivitas $\geq 0,30$ (Aiken, 1997).

\section{Analisis Keterlaksanaan Pembelajaran}

Data keterlaksanaan pembelajaran dianalisis menggunakan analisis deskriptif kualitatif. Penilaian ini meliputi pendahuluan, kegiatan inti, dan penutup, dengan merata-rata skor masing-masing komponen dan hasil skor rata-rata dikonversi menggunakan kriteria sebagai berikut:

Tabel 3. Kriteria Keterlaksanaan RPP

\begin{tabular}{|l|l|}
\hline \multicolumn{1}{|c|}{ Selang } & \multicolumn{1}{c|}{ Kriteria } \\
\hline $1,00-1,99$ & Tidak terlaksana dengan baik \\
\hline $2,00-2,99$ & Terlaksana dengan kurang baik \\
\hline $3,00-3,49$ & Terlaksana dengann baik \\
\hline $3,50-4,00$ & Terlaksana dengan sangat baik \\
\hline
\end{tabular}

4. Analisis Data Pengamatan aktivitas Siswa

Teknik yang digunakan untuk menganalisis data pengamatan aktivitas siswa adalah statistik deskriptif kuantitatif, yaitu dengan menghitung frekuensi tiap kegiatan yang dilakukan siswa dibagi dengan seluruh kegiatan dikalikan dengan $100 \%$ :

$$
\mathrm{P}=\frac{\text { Frekuensi kegiatan tertentu }}{\text { Jumlah seluruh kegiatan siswa }} \times 100 \%
$$

\section{Data angket Motivasi Siswa}

Data motivasi siswa dianalisis secara deskriptif kuantitatif dan langkah-langkah yang digunakan dalam analisis motivasi belajar siswa adalah sebagai berikut :

1) Memberikan penilaian terhadap masing-masing aspek motivasi belajar siswa sesuai dengan kriteria yang telah ditentukan.

2) Menjumlahkan masing-masing aspek motivasi belajar siswa.

3) Mempersentasekan skor untuk masing-masing aspek motivasi siswa yang diamati menggunakan rumus :

$$
P=\frac{m}{M} x 100 \%
$$

Keterangan:

$$
\begin{aligned}
& \mathrm{P}=\text { persentase skor motivasi yang dicapai siswa } \\
& \mathrm{m}=\text { skor yang diperoleh siswa (skor motivasi) } \\
& \mathrm{M}=\text { skor maksimal motivasi }
\end{aligned}
$$

Hasil yang diperoleh diinterpretasi dengan menggunakan kriteria pada Tabel 4. 
Tabel 4. Kriteria Interpretasi Skor Motivasi Belajar Siswa

\begin{tabular}{|c|c|}
\hline Persentase Motivasi & Kriteria Motivasi \\
\hline $86 \% \leq \mathrm{P} \leq 100 \%$ & Sangat baik \\
\hline $72 \% \leq \mathrm{P}<86 \%$ & Baik \\
\hline $58 \% \leq \mathrm{P}<72 \%$ & Cukup baik \\
\hline $44 \% \leq \mathrm{P}<58 \%$ & Kurang baik \\
\hline $30 \% \leq \mathrm{P}<44 \%$ & Tidak baik \\
\hline
\end{tabular}

\section{Uji Hipotesis Korelatif}

Korelasi atau hubungan antara hasil belajar dengan motivasi siswa diuji menggunakan Uji korelasi Spearman menggunakan program Statistical Package for Social Science (SPSS) versi 16.0.

Tabel 5. Interpretasi Koefisien Korelasi Nilai $r$

\begin{tabular}{|c|c|}
\hline Interval Koefisien & Tingkat Hubungan \\
\hline $0.00-0.199$ & Sangat rendah \\
\hline $0.20-0.399$ & Rendah \\
\hline $0.40-0.599$ & Cukup \\
\hline $0.60-0.799$ & Kuat \\
\hline $0.80-1.000$ & Sangat Kuat \\
\hline
\end{tabular}

(Riduwan, 2013)

\section{HASIL PENELITIAN DAN DISKUSI}

A. Deskripsi Hasil Pengembangan Perangkat dan Media Pembelajaran

1. Hasil Validasi Rencana Pelaksanaan Pembelajaran (RPP)

Skor rata rata validasi yang diperoleh adalah 3,77 dengan kategori baik, sehingga RPP yang telah divalidasi dapat digunakan dalam kegiatan pembelajaran.

\section{Hasil Validasi Lembar Kerja Siswa (LKS)}

Bahwa rata-rata skor penilaian LKS dari validator adalah 3.67 sehingga berkategori baik dan selanjutnya dapat digunakan dalam pembelajaran.

\section{Hasil Validasi Penilaian (Tes Hasil Belajar)}

Berdasarkan hasil validasi tes hasil belajar yang dikembangkan, secara umum berkategori cukup valid dan dapat dipahami. Setelah mengalami revisi sesuai saran dan masukan dari validator maka instrumen tes hasil belajar tersebut layak dipergunakan untuk mengukur hasil belajar siswa.

\section{Hasil Validasi Media Game Edukasi}

Game edukasi yang dikembangkan mencakup materi: struktur dan fungsi saraf, mekanisme penghantaran impuls saraf, susunan sistem saraf, macam-macam gerak, serta penyakit dan kelainan pada sistem saraf. Materi dalam game edukasi tersebut secara rinci disajikan dalam Tabel 6.

Tabel 6. Materi Ajar dalam Game Edukasi.

\begin{tabular}{|c|c|c|}
\hline $\begin{array}{c}\text { Jenis Area } \\
\text { Game } \\
\text { Edukasi }\end{array}$ & Materi & Isi Game Edukasi \\
\hline $\begin{array}{l}\text { Area } 1 \\
\text { (pertemuan } \\
\text { I) }\end{array}$ & $\begin{array}{l}\text { Struktur, } \\
\text { fungsi, dan } \\
\text { mekanisme } \\
\text { dalam sistem } \\
\text { saraf }\end{array}$ & $\begin{array}{l}\text { Struktur sel saraf, } \\
\text { fungsi sel saraf, } \\
\text { perambatan impuls } \\
\text { saraf, mekanisme } \\
\text { penghantaran impuls } \\
\text { saraf, sinapsis, soal- } \\
\text { soal latihan. }\end{array}$ \\
\hline $\begin{array}{l}\text { Area } 2 \\
\text { (Pertemuan } \\
\text { II) }\end{array}$ & $\begin{array}{l}\text { Susunan } \\
\text { sistem saraf }\end{array}$ & $\begin{array}{l}\text { Struktur sistem saraf } \\
\text { pusat, fungsi sistem } \\
\text { saraf pusat, struktur } \\
\text { sistem saraf tepi, } \\
\text { fungsi sistem saraf } \\
\text { tepi, soal-soal latihan. }\end{array}$ \\
\hline $\begin{array}{l}\text { Area } 3 \\
\text { (Pertemuan } \\
\text { III) }\end{array}$ & $\begin{array}{l}\text { Macam- } \\
\text { macam gerak, } \\
\text { penyakit dan } \\
\text { kelainan pada } \\
\text { sistem saraf } \\
\text { manusia, }\end{array}$ & $\begin{array}{l}\text { Definisi dan contoh } \\
\text { gerak sadar, definisi } \\
\text { dan contoh gerak } \\
\text { refleks, penyakit dan } \\
\text { kelainan pada sistem } \\
\text { saraf manusia, soal- } \\
\text { soal latihan. }\end{array}$ \\
\hline $\begin{array}{l}\text { Area Final } \\
\text { (pertemuan } \\
\text { III) }\end{array}$ & $\begin{array}{l}\text { Mencakup } \\
\text { keseluruhan } \\
\text { materi ajar }\end{array}$ & Soal-soal latihan. \\
\hline
\end{tabular}

B. Deskripsi Hasil Pelaksanaan Perangkat Pembelajaran

1. Keterlaksanaan Rencana Pelaksanaan Pembelajaran (RPP)

keterlaksanaan RPP dapat dilihat pada Gambar 2 berikut:

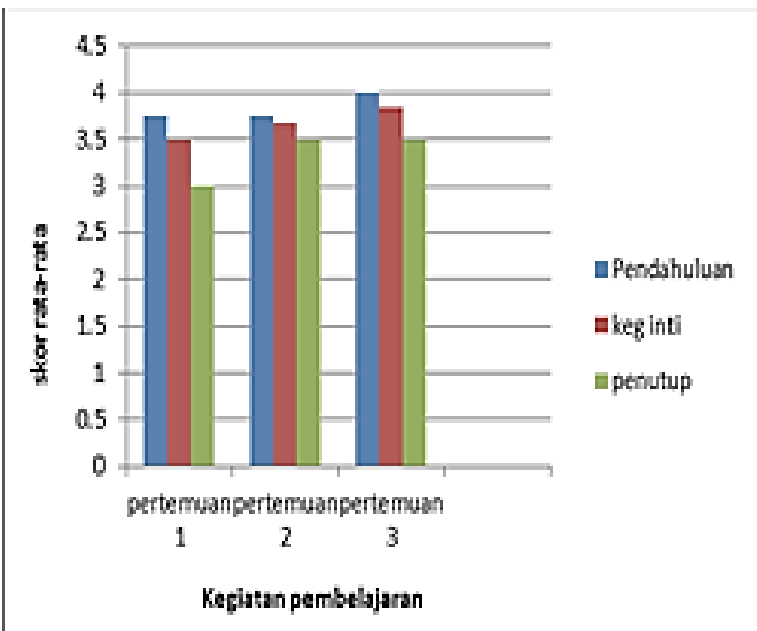

Gambar 2. Diagram Keteraksanaan RPP pada tiap pertemuan.

Berdasarkan diagram tersebut diperoleh informasi bahwa secara umum keterlaksanaan RPP berkategori sangat baik dengan reliabilitas $96.96 \%$. Penilaian aspek pendahuluan, kegiatan inti, dan penutup secara berurutan memiliki skor rata-rata 3.83 ; 3.67; dan 3.33, 
hal ini menunjukkan bahwa secara umum kegiatan pembelajaran berjalan dengan sangat baik karena skor rata-rata seluruh aspek dalam penilaian keterlaksanaan RPP berkategori sangat baik.

Hal tersebut menunjukkan bahwa kemampuan guru dalam mengelola kegiatan pembelajaran menggunakan model pengajaran langsung yang dipadukan dengan game edukasi pada materi sistem saraf secara umum dapat dikategorikan baik karena guru mampu mengelola pembelajaran sesuai dengan skenario yang tertuang dalam RPP. Hal tersebut tidak terlepas pula dari kematangan persiapan sebelum dilaksanakannya pembelajaran. Mengingat efisiensi waktu dan media yang digunakan membutuhkan proses install program flash player pada tiap komputer yang akan digunakan oleh siswa pada laboratorium multimedia sehingga proses install telah disiapkan dengan baik oleh peneliti sebelum pembelajaran berlangsung. Keterlaksanaan RPP yang berkategori baik juga menunjukkan bahwa RPP yang dikembangkan berkualitas baik dan telah memenuhi komponen RPP sesuai permendiknas No 41 tahun 2007 tentang Standar Proses yang menyatakan bahwa komponen RPP terdiri atas identitas mata pelajaran, standar kompetensi, kompetensi dasar, indikator pencapaian kompetensi, tujuan pembelajaran, materi ajar, alokasi waktu, metode pembelajaran, kegiatan pembelajaran (yang terdiri atas pendahuluan, isi, dan penutup), sumber belajar, serta penilaian hasil belajar.

\section{Aktivitas Siswa dalam Kegiatan Pembelajaran}

Aktivitas siswa secara berurutan dari nilai rata-rata tertinggi menuju terendah adalah mengoperasikan game edukasi (34.85\%), mengerjakan LKS (31.22\%), memperhatikan penjelasan guru $(27.80 \%)$, menjawab atau menanggapi diskusi pembahasan LKS (2.01\%), membuat kesimpulan $(1.72 \%)$, menjawab pertanyaan guru $(1.26 \%)$, bertanya kepada guru $(1.16 \%)$, dan aktivitas tidak relevan $(0.21 \%)$.

Aktivitas siswa dalam mengoperasikan game edukasi dan mengerjakan LKS memiliki rata-rata frekuensi tinggi menunjukkan bahwa media dan perangkat yang dikembangkan memberikan kontribusi positif bagi aktivitas belajar siswa sehingga siswa dapat terlibat secara aktif dalam pembelajaran menggunakan media game edukasi Hal itu juga menunjukkan bahwa game edukasi yang dikembangkan dapat menyebabkan siswa untuk tetap mempertahankan perhatian mereka terhadap proses pembelajaran terutama pada pemahaman konsep yang terdapat dalam game edukasi. Hal ini sejalan dengan Arends (2008) yang menyatakan bahwa dengan mempelajari tutorial dan berinteraksi dengan simulasi komputer membantu memberikan berbagai tantangan yang menarik kepada siswa dan membantu mereka mempertahankan aktivitas mental yang dibutuhkan dan mempelajari informasi dan ide-ide yang bermakna.

Aktivitas lain yang juga memiliki frekuensi tinggi adalah memperhatikan penjelasan guru, hal ini disebabkan karena pada penelitian ini pembelajaran menggunakan model pengajaran langsung sehingga bimbingan dan penjelasan dari guru tetap diperlukan dan dilakukan, selain itu game edukasi yang dikembangkan berisi konsep-konsep dasar materi sistem saraf sehingga untuk pendalaman konsep masih memerlukan penjelasan dan bimbingan dari guru. Akan tetapi dikarenakan penerapan model pengajaran langsung dalam pembelajaran tidak boleh menjadikan siswa pasif dan hanya menerima penjelasan konsep dari guru saja, sehingga peneliti memadukan model pengajaran langsung dengan game edukasi. Hal ini sejalan dengan Moore (2007) yang menjelaskan bahwa seorang guru yang mengajar dengan model pengajaran langsung adalah pengajar yang efektif. Pengajar efektif adalah mereka yang berusaha mengatasi kesulitankesulitan dalam mencegah kegagalan peserta didik, mengkombinasikan strategi-strategi dan konsep pengajaran langsung dengan pendekatan-pendekatan mengajar lainnya. Arends (2008) juga menyatakan bahwa kunci riil untuk pengajaran langsung adalah kemampuan guru untuk menggunakan beragam repertoar pendekatan pengajaran yang memungkinkannya untuk mencocokkan pendekatan pengajaran itu dengan tujuan belajar tertentu dan kebutuhan siswa-siwa tertentu. Siswa SMA merupakan siswa kelompok kelas atas sehingga untuk menerapkan model pengajaran langsung berbeda metodenya dengan siswa-siswa kelas rendah. Untuk siswa kelas atas harus dibuat variasi pada struktur pelajarannya dengan cara memberikan kesempatan untuk eksplorasi dan juga membuat variasi pada presentasi dan demonstrasinya dengan cara memperluas keluar ide dan keterampilan dasar untuk mereka.

Game edukasi yang dikembangkan peneliti mengintegrasikan konsep-konsep dan latihan soal yang disajikan secara bertahap dan terstruktur dalam sebuah game atau permainan, dengan demikian diharapkan siswa menjadi tertarik sehingga dapat lebih mudah memahaminya dan dapat mengkonstruksi pengetahuan tersebut dalam benak mereka sendiri yang akan menjadikan pengetahuan tersebut melekat dalam memori jangka panjang mereka. Hal ini sesuai dengan Gagne (dalam Arsyad: 2007) yang menyatakan bahwa dalam pemrosesan informasi terjadi interaksi antara kondisi-kondisi internal dan kondisi-kondisi eksternal individu. Kondisi internal yaitu keadaan dalam diri individu yang diperlukan untuk mencapai hasil belajar dan proses kognitif yang terjadi dalam individu. Kondisi eksternal adalah rangsangan dari lingkungan yang mempengaruhi individu dalam proses 
pembelajaran (termasuk media pembelajaran). Informasi yang dipersepsi seseorang dan mendapat perhatian, akan ditransfer ke komponen kedua dari sistem memori, yaitu memori jangka pendek, dimana memori jangka pendek adalah sistem penyimpanan informasi terbatas hanya dalam beberapa detik sedangkan memori jangka panjang merupakan bagian dari sistem memori sebagai tempat menyimpan informasi untuk periode panjang.

Hasil pengamatan juga menunjukkan bahwa terdapatnya aktivitas yang tidak relevan siswa pada proses pembelajaran, meskipun dengan frekuensi aktivitas terendah, akan tetapi dikarenakan aktivitas tersebut mengalami penurunan frekuensi pada pertemuan selanjutnya sehingga dapat dikatakan bahwa game edukasi yang dipadukan dengan model pengajaran langsung dapat membuat siswa tertarik dan selanjutnya dapat terlibat secara aktif dalam pembelajaran.

\section{Ketuntasan Hasil Belajar Siswa}

Ketuntasan hasil belajar menggunakan media game edukasi digunakan untuk mengetahui tingkat penguasaan siswa atas materi pembelajaran. Ketuntasan hasil belajar dilihat dari ketercapaian indikator, ketuntasan individual, dan ketuntasan klasikal. Pada awal pembelajaran seluruh indikator tidak tuntas, namun pada akhir pembelajaran berdasarkan hasil posttest terlihat peningkatan jumlah indikator yang tuntas, meskipun tidak seluruhnya mengalami ketuntasan. Gambar 3 berikut menunjukkan ketuntasan indikator pada tiap-tiap indicator pembelajaran.

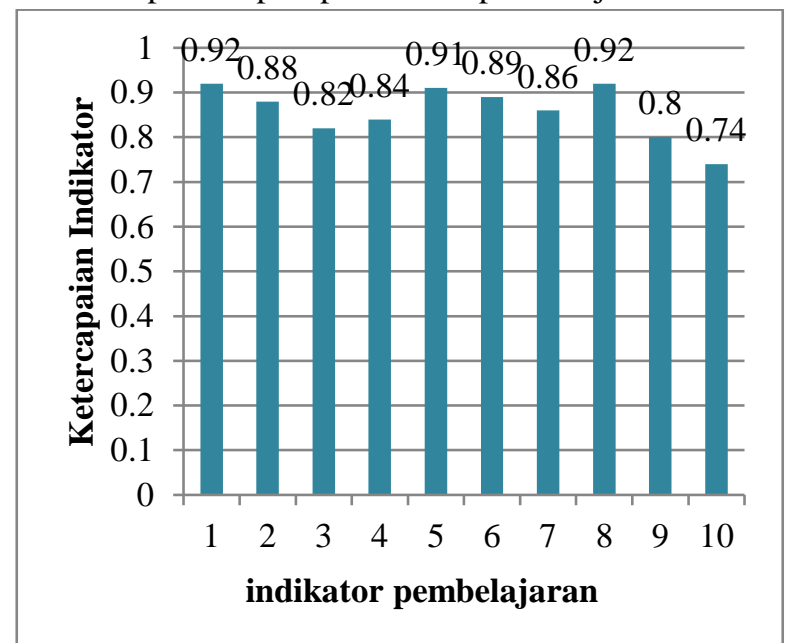

Gambar 3. Ketuntasan Indikator Pembelajaran

Berdasarkan diagram tersebut terlihat bahwa indikator pembelajaran nomor 10 yaitu: Membedakan jenis obat-obatan berdasarkan efeknya terhadap pemakainya dan pengaruhnya terhadap sistem saraf, memiliki ketercapaian indikator sebesar 0.74 sehingga dinyatakan tidak tuntas karena berada dibawah KKM. Jika dianalisa lebih lanjut, akan terlihat bahwa indikator ini terdiri atas tiga butir soal, yaitu soal nomor 22, 25, dan 26. Butir soal nomor 22 memiliki proporsi jawaban benar sebesar 0.78 yang menunjukkan bahwa jumlah siswa yang menjawab benar pada posttest sebesar $78 \%$ sehingga bisa dikatakan berada diatas KKM. Demikian pula halnya dengan butir soal nomor 26 memiliki proporsi jawaban benar sebesar 0.77 sehingga berada dalam kategori tuntas. Berbeda halnya dengan butir soal nomor 25, proporsi jawaban benar saat posttest sebesar 0.66 dengan kata lain hanya $66 \%$ siswa yang menjawab benar pada saat posttest. Nilai ini berada dibawah KKM sehingga tidak tercapainya ketuntasan pada indikator nomor 10 cenderung dikarenakan proporsi posttest yang rendah pada soal nomor 25 . Hal ini kemungkinan disebabkan karena siswa belum terbiasa mengerjakan soal analisis dalam bentuk uraian, dan siswa kesulitan untuk menuangkan jalan berpikir dan kemampuan analisis mereka dalam bentuk kalimat uraian. Kemungkinan lain juga bisa disebabkan karena siswa memang belum terlalu memahami konsep yang berkaitan dengan tujuan pembelajaran nomor 25 sehingga guru disarankan untuk memberikan penjelasan atau pembelajaran lebih mendalam sehingga indikator tersebut dapat tuntas.

Hasil yang diperoleh pada penelitian ini juga menunjukkan bahwa pada pretest seluruh siswa tidak tuntas dengan ketuntasan klasikal sebesar $0 \%$ sedangkan pada posttest terdapat 3 orang siswa yang tidak tuntas dan 33 orang siswa tuntas sehingga ketuntasan klasikal sebesar $91.67 \%$, dengan demikian dinyatakan tuntas secara klasikal karena berada diatas $\operatorname{KKM}(\geq 75 \%)$.

Penelitian ini juga menganalisis mengenai sensitivitas butir soal. Berdasarkan hasil penelitian diketahui bahwa seluruh butir soal yang diujikan berada dalam kisaran sensitivitas $0.19-0.90$, dari 26 butir soal terdapat 25 soal yang sensitif karena memiliki nilai sensitivitas $\geq 30 \%$ dan satu butir soal yang tidak sensitif karena memiliki indeks sensitivitas butir soal hanya sebesar 0.19 , yakni pada soal nomor 18 . Soal tersebut dalam bentuk pilihan ganda dan soal berkaitan dengan contoh gerak refleks. Pada saat pretest proporsi jawaban benar siswa pada butir soal tersebut sebesar 0.81 dan proporsi jawaban benar pada saat posttest sebesar 1. Hal tersebut mengindikasikan bahwa soal tersebut dapat dijawab oleh hampir sebagian besar siswa ketika pretest yang kemungkinan disebabkan karena item pilihan jawaban yang tersedia terlalu mudah sehingga jawaban kunci dapat dijawab dengan mudah dan bahkan mungkin pada beberapa orang siswa dapat menjawab benar meskipun hanya dengan menebak jawaban yang benar dikarenakan hampir sebagian orang akan mengerti bahwa minum karena haus, yang merupakan jawaban kuncinya, merupakan kegiatan yang bukan termasuk gerakan refleks. 
Butir soal yang berada dalam kategori sensitive sejumlah 25 butir soal karena berada pada kisaran nilai $\geq 30 \%$. Hal tersebut menunjukkan bahwa butir soal tersebut adalah peka sehingga keberhasilan siswa dalam menjawab butir soal dapat dinyatakan sebagai pengaruh atau efek dari pembelajaran menggunakan model pengajaran langsung yang dipadukan dengan media game edukasi yang telah digunakan. Keberhasilan dalam pembelajaran juga dapat terlihat dari nilai $\mathrm{N}$-gain sebesar 0.77 sehingga berada dalam kategori tinggi dan nilai tersebut menunjukkan perbedaan penguasaan atau pemahaman konsep siswa sebelum dan setelah perlakuan adalah tinggi, dengan kata lain pemahaman konsep siswa setelah melewati pembelajaran meningkat dibandingkan dengan pemahaman konsep mereka sebelum pembelajaran dilakukan.

\section{Motivasi siswa}

Motivasi belajar siswa diukur dengan memberikan angket motivasi di akhir pembelajaran dan selanjutnya dilakukan penghitungan skor untuk tiap aspek attention, relevance, confidence, dan satisfaction. Aspek attention dengan persentase skor rata-rata 79.68, aspek relevance 80.48 , aspek confidence 74.22 , dan aspek satisfaction 82.96, sehingga secara keseluruhan motivasi belajar siswa termasuk dalam kategori baik. Hal ini menunjukkan bahwa perhatian siswa terhadap pembelajaran, relevansi pembelajaran dengan kebutuhan dan pengetahuan siswa, rasa percaya diri siswa untuk berhasil dalam pembelajaran, dan kepuasan siswa mengikuti proses pembelajaran adalah baik.

Aspek attention yang baik menunjukkan bahwa siswa dapat mempertahankan perhatian hingga akhir pembelajaran dengan baik. Hal tersebut tidak terlepas dari media game edukasi yang digunakan, karena menurut Keller (1987) pemanfaatan games, tehnik bermain peran maupun simulasi merupakan metode yang efektif untuk meningkatkan dan mempertahankan perhatian siswa. Aspek relevance yang baik menunjukkan bahwa siswa dapat menghubungkan pembelajaran yang dialaminya dengan pengetahuan mereka sebelumnya dan dapat menemukan manfaat belajar sistem saraf dalam kehidupan mereka sehari-hari maupun masa depan mereka. Mempelajari sistem saraf dan penerapannya membuat siswa dapat memahami dengan baik bagaimana pengaruh buruk narkoba terhadap sistem saraf mereka yang dapat merusak kehidupan maupun masa depan mereka sehingga pembelajaran relevan dengan kebutuhan siswa. Sanjaya (2008) mengemukakan bahwa salah satu upaya membangkitkan motivasi siswa adalah dengan membangkitkan minat siswa. Minat siswa akan tumbuh manakala ia dapat menangkap bahwa materi pelajaran itu berguna untuk kehidupannya, sehingga sangat penting bagi guru untuk menjelaskan keterkaitan materi pelajaran dengan kebutuhan siswa.

Aspek confidence yang baik menunjukkan bahwa siswa memiliki rasa percaya diri dalam mengikuti aktivitas pembelajaran. Game edukasi yang digunakan dalam pembelajaran sistem saraf membantu siswa merasa nyaman dan tidak khawatir berbuat salah dalam proses belajar karena siswa belajar memahami konsep melalui sebuah game dengan sedikit intervensi dari guru sehingga perasaan takut berbuat salah lebih dapat diminimalisir. Seperti yang dikemukakan Keller (1987) bahwa siswa yang memiliki rasa percaya diri yang tinggi memiliki kecenderungan untuk terlibat dalam seluruh aktivitas pembelajaran dan mereka menikmati pembelajaran meskipun dalam proses tersebut mereka melakukan suatu kesalahan.

Aspek satisfaction dengan kategori baik menunjukkan bahwa siswa puas dengan proses pembelajaran yang telah berlangsung. Hal itu tidak terlepas dari peranan guru yang konsisten memberikan penghargaan dan penguatan kepada siswa saat siswa berhasil menjawab pertanyaan, demikian pula guru memberikan jawaban yang memuaskan ketika siswa bertanya. Selain itu, game edukasi yang digunakan dalam pembelajaran memberikan kontribusi positif dalam kepuasan siswa karena dalam game edukasi diintegrasikan sistem penghitungan skor tiap kali siswa berhasil terus maju ke slide pembelajaran berikutnya dan berhasil menjawab pertanyaan dalam tantangantantangan game edukasi, serta pemberian lencana di akhir area permainan.

Pemberian penguatan tersebut diharapkan dapat meningkatkan motivasi belajar siswa. Usman (2011) menyatakan bahwa penguatan (reinforcement) mempunyai pengaruh positif terhadap proses belajar siswa dan bertujuan untuk meningkatkan perhatian siswa terhadap pembelajaran, serta merangsang dan meningkatkan motivasi belajar. Selain itu, Arends (2008) juga menyatakan bahwa program software yang dikembangkan dengan menggunakan teori penguatan maupun fitur seperti permainan dan kompetitif pada umumnya bersifat motivasional bagi kebanyakan anak. Software yang dikembangkan menggunakan teori penguatan menyebabkan ketika penggunanya mengidentifikasi jawaban yang benar atau menunjukkan perilaku yang diinginkan, sebuah hadiah diberikan untuk menguatkan dan atau membuat penggunanya mengulangi perilaku tersebut.

Empat aspek motivasi tersebut yang secara keseluruhan berkategori baik menunjukkan bahwa perangkat dan media game edukasi yang dipadukan dengan pembelajaran langsung pada materi sistem saraf yang diajarkan memberikan kontribusi positif terhadap motivasi siswa, sebagaimana halnya disimpulkan pula oleh Park (2012) bahwa pembelajaran berbasis game 
dapat meningkatkan motivasi siswa. Yeung (2009) juga menyimpulkan bahwa ketertarikan dan motivasi siswa dapat ditingkatkan dengan menggunakan modul kimia online yang mengintegrasikan animasi dalam pembelajaran sehingga dapat meningkatkan hasil belajar siswa.

5. Korelasi Antara Motivasi dan Hasil Belajar Siswa

Berdasarkan hasil analisis uji korelasi antara motivasi dan hasil posttest siswa diperoleh koefisien korelasi (r) sebesar 0.554 dengan $\mathrm{p}=0.000$. Hal tersebut menunjukkan bahwa korelasi motivasi dengan nilai posttest siswa adalah signifikan dengan kekuatan korelasi yang cukup kuat (Riduwan, 20013), sehingga dapat dinyatakan bahwa semakin tinggi motivasi siswa maka semakin tinggi pula nilai posttest yang diperoleh.

Berdasarkan hasil angket motivasi siswa diperoleh rerata aspek attention dengan persentase sebesar 79.68, aspek relevance 80.48 , aspek confidence 74.22 , dan aspek satisfaction 82.96 , sehingga secara keseluruhan motivasi belajar siswa termasuk dalam kategori baik. Hal tersebut menunjukkan bahwa selama proses pembelajaran, media game edukasi dan perangkat yang digunakan dapat membantu siswa untuk tetap mempertahankan motivasi belajar mereka tetap baik sehingga dapat berperan dalam menghasilkan ketuntasan belajar siswa yang dibuktikan dengan tercapainya ketuntasan klasikal sebesar $91.67 \%$ dan rerata $\mathrm{N}$-gain score yang tinggi.

Korelasi yang signifikan dan positif antara motivasi dan hasil belajar siswa yang diperoleh pada penelitian ini sejalan dengan hasil penelitian Lemos\&Verissimo yang juga menunjukkan bahwa terdapat korelasi positif yang signifikan antara motivasi intrinsik dengan pencapaian akademik siswa, dan korelasi yang tidak signifikan antara motivasi ekstrinsik dan pencapaian akademik siswa. Lemos\&Verissimo menyatakan pula bahwa motivasi intrinsik siswa lebih berperan dalam menentukan hasil belajar siswa dibandingkan dengan peranan motivasi ekstrinsik, meskipun bukan berarti motivasi ekstrinsik tidak penting. Sejalan dengan Sanjaya (2008) yang menyatakan bahwa dalam proses pembelajaran, motivasi intrinsik sulit untuk diciptakan oleh karena motivasi ini datangnya dari dalam diri siswa. Guru tidak akan tahu seberapa besar motivasi intrinsik yang menyertai perbuatan siswa, yang mungkin dapat dilakukan adalah dengan mengembangkan motivasi ekstrinsik untuk menambah dorongan kepada siswa agar lebih giat belajar.

\section{KESIMPULAN}

\section{A. Simpulan}

Berdasarkan hasil penelitian dan pembahasan dapat disimpulkan bahwa pengembangan perangkat pmbelajaran sistem saraf berorientasi strategi metakognitif yang disertai multimedia interaktif untuk mengembangkan karkter mandiri, memenuhi kriteria validitas, keefektifan dan mengembangkan karakter mandiri layak digunakan.

\section{B. Saran}

1. Pengembangan perangkat pembelajaran dan media game edukasi yang dipadukan dengan model pengajaran langsung pada KTSP dapat meningkatkan hasil belajar siswa sehingga diharapkan selanjutnya ada penelitian serupa yang menerapkannya pada kurikulum 2013.

2. Secara keseluruhan pengembangan perangkat pembelajaran dan media game edukasi yang dipadukan dengan model pengajaran langsung pada materi sistem saraf dapat meningkatkan hasil belajar siswa sehingga diharapkan selanjutnya ada penelitian serupa yang mengembangkan media game edukasi pada materi biologi yang lain.

3. Pengembangan perangkat pembelajaran menggunakan media game edukasi dapat meningkatkan motivasi siswa sehingga diharapkan dilakukan penelitian lanjutan dengan pengembangan sikap siswa yang lain.

4. Pengisian angket motivasi ARCS oleh siswa pada penelitian ini dilakukan hanya pada akhir pembelajaran sehingga tidak dapat diketahui dengan pasti peningkatan motivasi belajar siswa sehingga diharapkan pada penelitian selanjutnya pengisian angket motivasi oleh siswa dapat dilakukan pada awal dan akhir pembelajaran sehingga dapat diketahui besarnya peningkatan motivasi belajar siswa.

\section{REFERENSI}

Arends, R.I. (2012). Learning to teach. Ninth edition. New York: McGraw Hill Companies.

Hamalik, O. (1994). Media pendidikan. Bandung: PT. Citra Aditya Bakti

Keller, J.M., (1987). "Development and use of the ARCS model of motivational design". Journal of instructional development. pp.1-10.

Lemos, M.S., and Verissimo, L., (2014). The relationship between intrinsic motivation, extrinsic motivation, and achievement, along elementary school. Procedia-Social and Behavioral Sciences. Vol. 112. Pp.930-938.

Moore, D.W. (2007). Direct instruction: targeted strategies for student succes. (Online). Tersedia http://www.ngsp.net/portals/o/downloads/pdf.

Mulyani, A. (2009). Pembelajaran sistem saraf berbasis tekhnologi informasi untuk meningkatkan penguasaan konsep, keterampilan generik sains, dan keterampilan berpikir kritis siswa (Tesis magister pendidikan tidak dipublikasikan). UPI 
Bandung.

Park, H., (2012). Relationship between motivation and student's activity on educational game. International journal of grid and distributed computing. Vol 5. No 1.

Sanjaya, W. (2008). Kurikulum dan pembelajaran:
Teori dan praktik pengembangan kurikulum tingkat satuan pendidikan (KTSP). Jakarta: Prenada Media Group

Usman, M.U. (2011). Menjadi guru professional. Bandung: PT Remaja Rosdakarya 